Dasril Daud • Alida Harahap • Iswari Setianingsih

Ita Nainggolan · Sunar Tranggana - Ruland Pakasi

Sangkot Marzuki

\title{
The Hemoglobin 0 mutation in Indonesia: distribution and phenotypic expression
}

\begin{abstract}
We have investigated hemoglobin O Indonesia $\left(\mathrm{HbO}_{\text {Ina }}\right)$ in related ethnic populations of the Indonesian archipelago: 1725 individuals of the five ethnic populations of South Sulawesi (Bugis, Toraja, Makassar, Mandar, and Kajang) and 959 individuals of the neighboring islands, who were divided into five phylogenetic groups: (a) Batak; (b) Malay from Padang, Pakanbaru, and Palembang in the island of Sumatra; (c) Javanese-related populations (Java, Tengger, and Bali) from the islands of Java and Bali; (d) populations of the Lesser Sunda Islands of Lombok, Sumba, and Sumbawa; and (e) the Papuan-languagespeaking population of Alor Island. Nineteen individuals heterozygous for $\mathrm{HbO}_{\text {Ina }}$ were identified from the Bugis, Toraja, Makassar, and Kajang ethnic populations, but none from the other populations. In all cases, the underlying mutation was found to be in codon 116 (GAG to AAG) of the $\alpha_{1}$-globin gene, resulting in the Glu116Lys amino acid change. The level of $\mathrm{HbO}$ in the 17 individuals plus 12 additional family members carrying the mutation was found to be $11.6 \pm 1.0 \%$, significantly lower than the expected $17 \%-22 \%$, indicating the instability of $\mathrm{HbO}$.
\end{abstract}

Key words Hemoglobinopathy · Hemoglobin O Indonesia • $\alpha$-Globin gene $\cdot \beta$-Thalassemia

D. Daud $\cdot S$. Tranggana $\cdot$ R. Pakasi

Departments of Pediatric and Clinical Pathology, Hasanuddin

University, Ujung Pandang, Indonesia

A. Harahap

Department of Clinical Pathology, University of Indonesia, Jakarta Indonesia

A. Harahap · I. Setianingsih · I. Nainggolan · S. Marzuki ( $\square)$

Eijkman Institute for Molecular Biology, Jl. Diponegoro 69, Jakarta

10430, Indonesia

Tel. +62-21-3148694; Fax +62-21-3147982

e-mail: smarzuki@eijkman.go.id

\section{Introduction}

Hemoglobin $\mathrm{O}$ Indonesia $\left(\mathrm{HbO}_{\text {Ina }}\right)$ is a hemoglobin $(\mathrm{Hb})$ variant that was first reported in the Bugis population of Sulawesi Island in Indonesia, and hence designated originally as hemoglobin Buginese-X (Lie Injo 1957; Lie Injo and Sadono 1957). A phenotypically similar $\mathrm{HbO}$ was reported in an Iranian family (Rahbar et al. 1975) and in an Italian (Marinucci et al. 1978) family. In all of these cases, the mutation could be shown by tryptic digestion experiments to be associated with an amino acid change at residue 116 (Glu116Lys) of the $\alpha$-globin chain. The underlying mutation, however, has been defined only in one case of undefined ethnic origin, a GAG to AAG base substitution at codon 116 of the $\alpha_{1}$-globin gene (Molchanova et al. 1994).

Except for a few anecdotal mentions (Lie Injo 1957; Lie Injo and Sadono 1957), the distribution of $\mathrm{HbO}_{\mathrm{Ina}}$ in related Indonesian populations has not been investigated. The Southeast Asian archipelago is inhabited by more than 350 ethnic populations. While these populations have distinct languages and cultural characteristics, with the exception of those of Papua/New Guinea and certain islands in east Indonesia, they are related to the Bugis in that they belong to the Malayo-Polynesian branch of the Austronesian linguistic family (Pelras 1996; Bellwood 1995). The current ethnic diversity is believed to have arisen as the result of a progressive migration of a proto-Austronesian-speaking Southern Mongoloid ancestral population into a continuum of preexisting Melano-Austroloid populations, the major part of which took place between 5000 and 2500 years before present (Bellwood 1995). Information with regard to the frequency of $\mathrm{HbO}$ in the populations and the variation of its molecular basis, if any, is of interest in relation to (a) the prehistoric migratory origin of the populations, and (b) the possible medical relevance of the mutation as a modifier of the phenotypic expression of $\beta$-thalassemia mutations (Weatherall and Clegg 1981), which are common in the archipelago with carrier frequency ranging from $3 \%$ to more than $10 \%$ in certain ethnic populations (Sofro 1995). 
We have accordingly investigated $\mathrm{HbO}$ in five closely related populations of South Sulawesi (Bugis, Toraja, Makassar, Mandar, and Kajang), and in populations of the neighboring islands, which were divided into five phylogenetic groups: (a) Batak; (b) Malay-related populations of Padang, Pakanbaru, and Palembang, all on the island of Sumatra; (c) Javanese-related populations from Java, Tengger, and Bali; (d) populations of the Lesser Sunda Islands of Lombok, Sumba, and Sumbawa; and (e) the Papuan-language-speaking population of the Alor island.

\section{Subjects and methods}

Blood samples. Venous blood samples $(5-10 \mathrm{ml})$ were collected with informed consent from 1725 normal individuals of the Toraja (409), Makassar (361), Bugis (628), Mandar (238), and Kajang (89) ethnic populations. The Makassar, Bugis, Toraja, Mandar, and Kajang have distinct languages and cultural characteristics (Pelras 1996), but inhabit neighboring regions in the southern part of Sulawesi island in Indonesia (Fig. 1). This study was approved by the Human and Medical Ethics Committee of the University of Hasanuddin (No 02/DPE-K/99). DNA samples from 959 individuals of other ethnic populations of the Indonesian archipelago (123 Batak, 263 Malay, 216 Javanese-related, 297 of the Lesser Sunda islands, and 60 Alor) are from the collections of the Inter University Centre for Biotechnology of the University of Gadjah Mada and of the Eijkman Institute, collected as part of a larger program in the study of the population structure and genome diversity of the Indonesian archipelago. All samples were collected using sodium-ethylenediaminetetraacetate (EDTA) $(1.5 \mathrm{mg} / \mathrm{ml}$ final concentration) as an anticoagulant.
Hematological study and hemoglobin analysis. Hematological data [hemoglobin concentration, hematocrit, red-blood-cell count, and mean cell volume (MCV)] were obtained using an automatic cell counter (Cobas Micros OT 18; Roche, Basel, Switzerland). The presence of abnormal hemoglobin was examined by the electrophoretic examination of hemolysate using a Titan Gel kit (Helena Laboratories, Beaumont, TX, USA) on cellulose acetate at pH 8.6 (Tris EDTA-boric acid buffer; Helena Laboratories) (Fig. 2a). The levels of $\mathrm{HbA}_{2}$ and $\mathrm{HbO}$ were quantitated following chromatography on diethylaminoethanyl (DEAE) cellulose using the Hemoglobin $\mathrm{A}_{2}$ Micro Column (Bio-Rad, Hercules, CA, USA). $\mathrm{HbO}$ co-elutes with $\mathrm{HbA}_{2}$ in this microcolumn, but their relative amounts could be determined from the cellulose acetate electrophoretic pattern, employing a Bio-Rad Model GS-700 Imaging Densitometer for the quantitation of each. The accuracy and reproducibility of this procedure was validated using a Bio$\mathrm{Rad}$ Variant hemoglobin testing system ( $\beta$-thalassemia short program), which became available toward the end of this study; $\mathrm{HbO}$ and $\mathrm{HbA}_{2}$ are well separated in this analyzer (Fig. 2b). Eight of the last samples collected were quantitated for $\mathrm{HbO}$ by using the Bio-Rad Variant hemoglobin testing system only. The stability of $\mathrm{HbO}$ was evaluated by a thermal stability test (Brozovic and Henthorn 1995) and isopropanol test (Carrell and Kay 1972).

Strategy for the detection and mapping of the $H b O_{\text {Ina }}$ mutation. DNA was extracted from peripheral blood leukocytes essentially as described in the Puregene DNA extraction kit (Gentra, St. Paul, MN, USA), and used for polymerase chain reaction (PCR) analysis to specifically amplify 122- and 117-bp fragments of the $\alpha_{1}$ - and $\alpha_{2}$-globin genes, respectively (Fig. 3a). Three primers were employed: a specific forward primer for each of the $\alpha$-globin genes
Fig. 1. The Indonesian archipelago and ethnic populations investigated in this study. The insert shows the geographical relationships among the five ethnic populations of South Sulawesi

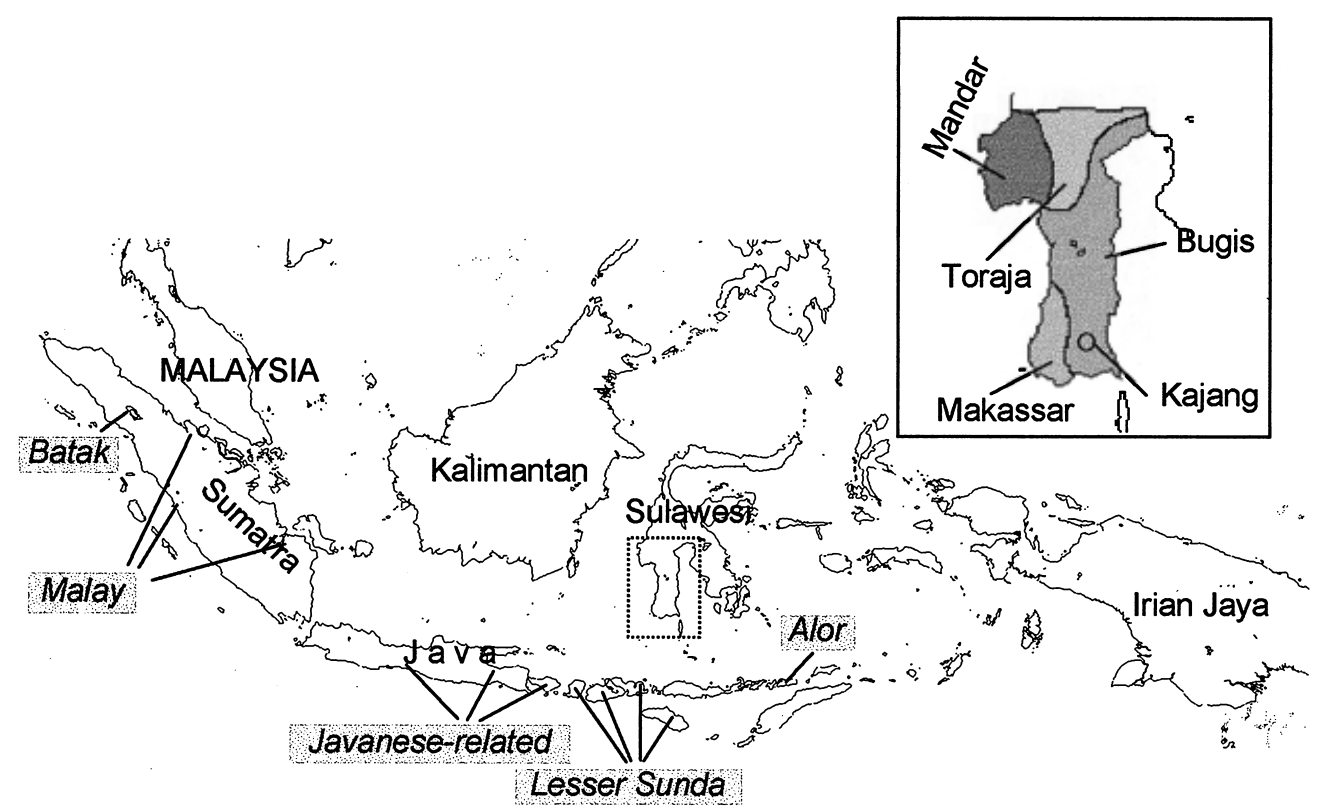


a

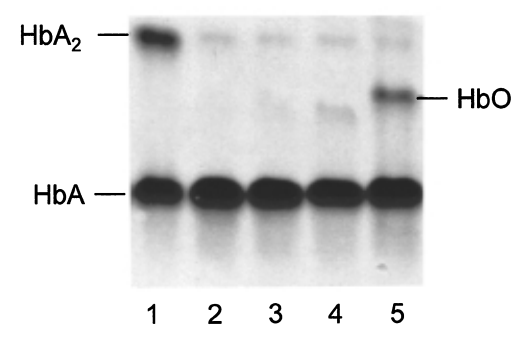

b
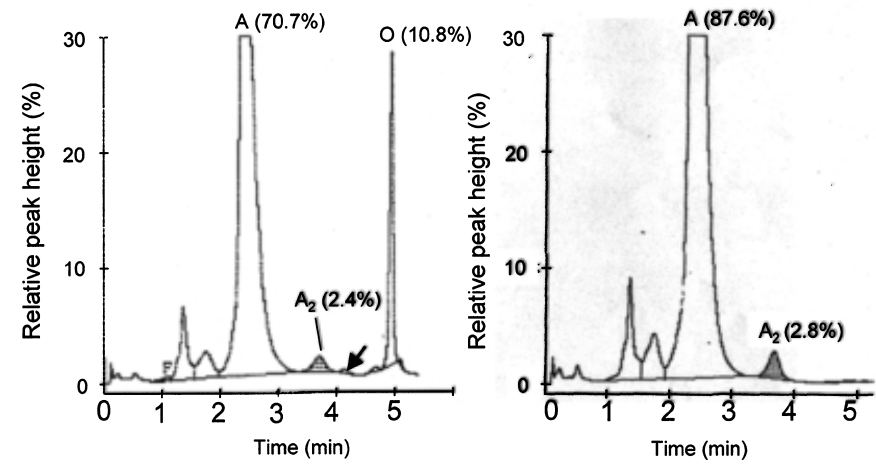

Fig. 2. Electrophoretic (a) and chromatographic (b) characteristics of hemoglobin $\mathrm{O}(\mathrm{HbO})$. Two methods were employed for the detection of $\mathrm{HbO}$. The initial screening was carried out by electrophoretic separation of the hemoglobin on cellulose acetate at $\mathrm{pH}$ 8.6. Shows the results of the analysis of an individual with $\mathrm{HbO}$ (lane 5), three normal individuals (lanes 2,3,4), and an individual heterozygous for $\mathrm{HbE}$ (lane 1 , showing one intense band for $\mathrm{HbA}_{2}+\mathrm{HbE}$, which have a similar electrophoretic mobility). Toward the end of this study, a Variant hemoglobin analyzer became available for the detection of the $\mathrm{HbO}$ mutation by high-performance liquid chromatography HPLC (b, left). An additional peak (arrow) presumably of $\mathrm{HbA}_{2}^{\mathrm{O}}\left(\alpha^{\text {Glu116Lys }} \mathrm{\delta}_{2}\right)$ is seen in the $\mathrm{HbO}$ patient (b, left) but not in the normal individual $(\mathbf{b}$, right $)$

$\left(\alpha_{1} 11031 \mathrm{~F}\right.$ or $\left.\alpha_{2} 7218 \mathrm{~F}\right)$, and a common reverse primer $\left(\alpha_{1} 11152 \mathrm{R}=\alpha_{2} 7334 \mathrm{R}\right)$, in which a nucleotide in the sequence has been modified to create a restriction site for HinfI at the position of codon 116 in the PCR-amplified $\alpha_{1}$ and $\alpha_{2}$-globin gene fragments (Fig. 3a). Digestion of the PCR products from the normal $\alpha_{1}$ - and $\alpha_{2}$-globin genes with HinfI produces 98- and a 24-bp fragments, and 93- and 24-bp fragments, respectively. The HinfI restriction site disappears if there is a mutation at codon 116 (Fig. 3b).

DNA sequencing. Amplified fragments of the $\alpha_{1}$-globin gene described above were cloned into Escherichia coli DH5 $\alpha$ using the pGEM-T vector system (Promega, Madison, WI, USA). The purified recombinant plasmid was used as the template in the sequencing of the insert in an $\mathrm{ABI}$ 377A sequencer employing dye terminator sequencing (Perkin Elmer, Foster City, CA, USA) with the T7 sequencing primer. a

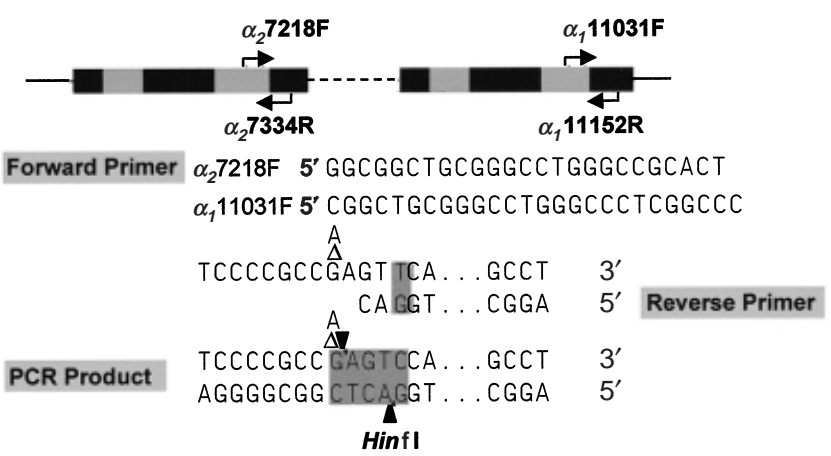

b

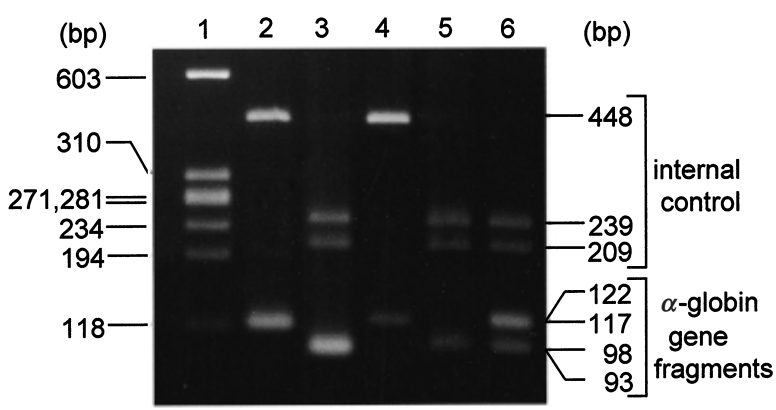

C
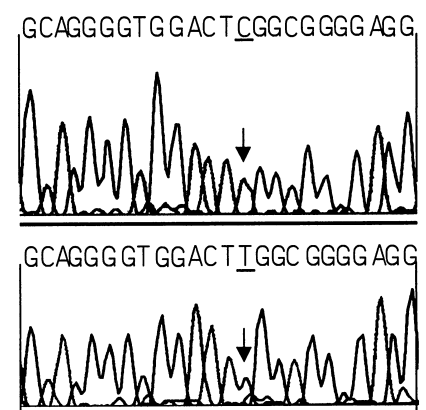

Fig. 3. The detection and mapping of the $\mathrm{HbO}_{\text {Ina }}$ mutation by polymerase chain reaction-restriction fragment length polymorphism. The strategy deviced (a) involved separate and specific amplifications of the $\alpha_{1}$ - and $\alpha_{2}$-globin gene fragments. $\alpha_{2} 7218 F$ and $\alpha_{1} 11031 F$ are specific forward primers for the amplification of the $\alpha_{2}$ - and $\alpha_{1}$-globin gene fragments, respectively. $\alpha_{2} 7334 R$ is identical to $\alpha_{1} 11152 R$, and is a common reverse primer containing a mismatch $(\mathrm{G} / \mathrm{T})$ to create a restriction site for HinfI enzyme at codon 116. Results obtained from representative samples are shown as an illustration (b). HinfI digestion of the amplified normal $\alpha_{2}$-globin gene fragment (lane 2 ) produces a 93and a 24-(not seen) bp fragment (lane 3). The digestion of the normal $\alpha_{1}$-globin gene fragment (lane 4) gives a 98- and a 24-(not seen) bp fragment (lane 5). $\mathrm{HbO}_{\text {Ina }}$ heterozygotes (lane 6) were found to produce a 98 -(for $\alpha_{1}$-globin) and a 24-bp fragment, and also a 122-bp uncut fragment of the $\alpha_{1}$-globin gene. The upper bands in lanes 3, 5, and 6 (239 and 209 bp) are HinfI digestion products of an internal control (a 448-bp DNA fragment) added to the reaction mixture (lanes 2 and 4) to monitor the completeness of the digestion. The mutation of codon 116 (GAG to AAG) of the $\alpha_{1}$-globin gene was confirmed by direct sequencing in an ABI 377A sequencer (c); $\downarrow$ indicates the site of the mutation 


\section{Results}

A total of 1725 phenotypically normal individuals from the five major ethnic populations of the southern region of the island of Sulawesi (Fig. 1) were examined for $\mathrm{HbO}$. The initial electrophoretic screen (Fig. 2a) revealed 19 individuals with $\mathrm{HbO}$ (Table 1). Of these individuals, 10 were of the Toraja ethnic population ( $n=409 ; 1.2 \%$ allele frequency), one was Makassar ( $n=361 ; 0.1 \%$ allele frequency), five were Bugis ( $n=628 ; 0.4 \%$ allele frequency), and three were Kajang ( $n=89 ; 1.7 \%$ allele frequency).

The 19 individuals with $\mathrm{HbO}$ were further examined to confirm that the underlying mutation was indeed associated with codon 116, and, at the same time, to investigate whether the mutation was on the $\alpha_{1}$ - or the $\alpha_{2}$-globin genes. Using the strategy outlined in Fig. 3a, all 19 cases were found to be associated with a point mutation on codon 116 of the $\alpha_{1}$-globin gene (Fig. 3b). The mutation was confirmed by DNA sequencing to be a GAG to AAG base substitution (Fig. 3c), resulting in a glutamic acid to lysine amino acid replacement (Glu116Lys). Employing the PCRrestriction fragment length polymorphism strategy above, 959 individuals from five other phylogenetic groups of the Indonesian populations were screened for the $\mathrm{HbO}$ mutation. However, the analysis did not reveal any $\mathrm{HbO}$-positive individual (Table 1).

We are interested in the phenotypic expression of the Glu116Lys amino acid replacement in the $\alpha$-globin molecule. To increase the number of cases available for this part of the study, we screened family members of the initial $19 \mathrm{HbO}$-heterozygotic individuals and found 13 more cases. As shown in Table 2, all but two of the 32 individuals with the HbO mutation exhibited normal or near normal hematological values, with the hemoglobin level ranging from 11.2 to $17.4 \mathrm{~g} / \mathrm{dl}$, a red blood cell count of 4.1 to $5.8 \times 10^{12} / 1$, a hematocrit value of $33.7 \%$ to $51.2 \%$, and mean cell volume (MCV) of 77 to $92 \mathrm{fl}$. One of the two exceptions was patient UP-410, who had a hemoglobin level of $10.3 \mathrm{~g} / \mathrm{dl}$, a hematocrit value of $30.7 \%$, and MCV of $68 \mathrm{fl}$, and who in the blood smear evaluation showed microcytic hypochrome

Table 1. Distribution of the $\mathrm{HbO}_{\mathrm{Ina}}$ mutation in Indonesia

\begin{tabular}{llll}
\hline Population & $\begin{array}{l}\text { No. of } \\
\text { individuals } \\
\text { examined }\end{array}$ & $\begin{array}{l}\text { Heterozygous } \\
\text { for HbO }\end{array}$ & $\begin{array}{l}\text { HbO } \\
\text { mutation- } \\
\text { (\% alleles) }\end{array}$ \\
\hline South Sulawesi & & & \\
$\quad$ Toraja & 409 & 10 & 1.2 \\
$\quad$ Makassar & 361 & 1 & 0.1 \\
$\quad$ Bugis & 628 & 5 & 0.4 \\
Mandar & 238 & 0 & 0 \\
$\quad$ Kajang & 89 & 3 & 1.7 \\
Javanese & 216 & 0 & 0 \\
Malay & 263 & 0 & 0 \\
Batak & 123 & 0 & 0 \\
Lesser Sunda Islands & 297 & 0 & 0 \\
Alor (Papuan-language- & 60 & 0 & 0 \\
$\quad$ speaking) & & &
\end{tabular}

$\mathrm{HbO}_{\text {Ina }}$, hemoglobin O Indonesia red blood cells. This patient, however, had a serum ferritin level of $4.3 \mu \mathrm{g} / \mathrm{l}$, indicating iron deficiency. The other exception was patient UP-519, who had a normal Hb level but a low MCV value, indicating that this individual was either an $\alpha$ - or $\beta$-thalassemia carrier. We note that while the hemoglobin level in the HbO-carrying individuals was mostly within the normal range, in a number of cases it was in fact at the lower end of or just below the range.

The mean $\mathrm{HbO}$ level was found to range from $10.1 \%$ to $13.8 \%$ of the total hemoglobin with a mean \pm SD of 11.6 $\pm 1.0 \%$, except for patients UP-1015 and KJG-16, who showed high $\mathrm{HbO}$ levels of $17.5 \%$ and $19.2 \%$, respectively, and patient TRJ-21, who had an unusually low $\mathrm{HbO}$ level of $4.5 \%$. The HbO levels in these three individuals have been confirmed by high-performance liquid chromatography (HPLC) using the Bio-Rad Variant hemoglobin testing system. The relatively high levels of $\mathrm{HbO}$ in patients UP-1015 and KJG-16 might be due to its co-inheritance with an $\alpha$ thalassemia mutation. The reduced production of $\alpha$-globin chain in $\alpha$-thalassemia would give the $\alpha^{\text {OIna }}$-globin chains a higher probability of forming $\mathrm{HbO}$. We have tested both UP-1015 and KJG-16 for the Southeast Asian $\alpha$-globin gene deletion, which accounts for approximately $90 \%$ of the $\alpha$ thalassemia mutations in the neighboring Southeast Asian countries (Ko et al. 1999). The mutation could not be detected in these two cases, but the possibility of other $\alpha$ globin defects still cannot be discounted. The low level of $\mathrm{HbO}$ in TRJ-21 could be caused by the co-inheritance of the $\mathrm{HbO}$ mutation with a $\beta$-thalassemia mutation. However, DNA analysis for $\beta$-globin gene defects could not detect any of the 19 most common $\beta$-thalassemia mutations in Indonesia (Setianingsih et al. 1998). It is interesting to note that the mother of TRJ-21 showed a HbO level of $13 \%$, while the father showed normal red cell indices and hemoglobin pattern.

The hemoglobin analysis using the Bio-Rad Variant hemoglobin testing system showed a small peak at about $4 \mathrm{~min}$ in addition to the $\mathrm{HbO}$ peak at $4.9 \mathrm{~min}$. This small peak was not found in the normal individuals (Fig. 2b), and thus is presumably $\mathrm{HbA}_{2}{ }^{\mathrm{O}}\left(\alpha^{\text {Glu116Lys }}{ }_{2} \mathrm{\delta}_{2}\right)$. The $\mathrm{HbO}$ was stable (data not shown) in both the thermal stability test (Brozovic and Henthorn 1995) and the isopropanol test (Carrell and Kay 1972).

\section{Discussion}

The present investigation represents the most extensive molecular epidemiological study of $\mathrm{HbO}$ that has been carried out to date, and it has revealed several interesting observations. First, our results provide evidence that, while on the one hand the distribution of $\mathrm{HbO}$ is confined to the ethnic populations of South Sulawesi, this hemoglobinopathy, originally designated hemoglobin Buginese- $X$, is in fact not restricted to the Bugis population. Indeed, the allele frequency was found to be $0.4 \%$ for the Bugis, only slightly higher than the level in the phylogenetically related Makassar population $(0.1 \%)$, but significantly lower than 
Table 2. Hematological findings in individuals heterozygous for the HbO Glu16Lys mutation in the $\alpha_{1}$-globin gene

\begin{tabular}{|c|c|c|c|c|c|c|c|c|}
\hline Subject & Sex & $\begin{array}{l}\mathrm{Hb} \\
(\mathrm{g} / \mathrm{dl})\end{array}$ & $\begin{array}{l}\text { Red blood } \\
\text { cell count, } \\
\left(\times 10^{-12} / 1\right)\end{array}$ & $\begin{array}{l}\text { Hematocrit } \\
(\%)\end{array}$ & $\begin{array}{l}\text { MCV } \\
\text { (fl) }\end{array}$ & $\begin{array}{l}\mathrm{HbA}_{2} \\
(\%)\end{array}$ & $\begin{array}{l}\mathrm{HbO} \\
(\% \text { total } \\
\mathrm{Hb})\end{array}$ & $\begin{array}{l}\text { Ferritin } \\
(\mu \mathrm{g} / \mathrm{l})\end{array}$ \\
\hline UP-029 & male & 13.4 & 5.2 & 47.4 & 92 & 1.0 & 10.4 & 110.0 \\
\hline UP-030 & male & 14.5 & 5.6 & 51.2 & 91 & 1.6 & 10.4 & 116.5 \\
\hline UP-084 & male & 12.8 & 4.5 & 40.2 & 90 & 0.5 & 12.1 & 80.0 \\
\hline UP-107 & female & 11.2 & 4.1 & 33.7 & 84 & 2.1 & 11.1 & 85.3 \\
\hline UP-184 & female & 13.0 & 5.1 & 38.9 & 77 & 0.5 & 12.1 & 112.0 \\
\hline UP-376 & female & 11.9 & 4.5 & 36.9 & 82 & 1.0 & 10.1 & 94.0 \\
\hline UP-1014 & female & 11.6 & 4.1 & 36.2 & 79 & 0.6 & 13.2 & 100.3 \\
\hline UP-1015 & male & 14.3 & 5.8 & 46.5 & 80 & 0.5 & 17.5 & 116.0 \\
\hline UP-410 & female & 10.3 & 4.5 & 30.7 & 68 & $0^{\mathrm{a}}$ & 10.3 & 4.3 \\
\hline UP-417 & male & 16.4 & 5.5 & 47.1 & 86 & 0.9 & 11.8 & 78.1 \\
\hline UP-511 & male & 15.0 & 5.8 & 44.2 & 86 & 1.2 & 11.1 & 80.0 \\
\hline UP-512 & female & 13.8 & 4.7 & 40.6 & 86 & $0^{\mathrm{a}}$ & 13.6 & 76.0 \\
\hline UP-516 & female & 13.6 & 4.5 & 38.0 & 85 & $0^{\mathrm{a}}$ & 11.9 & 98.5 \\
\hline UP-517 & male & 15.9 & 5.3 & 45.2 & 85 & $0^{\mathrm{a}}$ & 12.4 & 112.0 \\
\hline UP-518 & male & 14.9 & 5.2 & 42.7 & 82 & $0^{\mathrm{a}}$ & 12.4 & 98.7 \\
\hline UP-519 & female & 12.7 & 5.3 & 38.1 & 71 & $0^{\mathrm{a}}$ & 11.9 & 112.0 \\
\hline UP-515 & female & 13.3 & 4.8 & 38.6 & 80 & $\mathbf{0}^{\mathrm{a}}$ & 11.6 & 75.5 \\
\hline UP-522 & female & 13.6 & 4.8 & 40.0 & 83 & 1.1 & 11.0 & 96.4 \\
\hline UP-523 & male & 17.4 & 5.8 & 49.9 & 86 & 2.5 & 10.3 & 112.1 \\
\hline UP-524 & female & 14.9 & 4.9 & 41.6 & 84 & 1.3 & 10.3 & 117.3 \\
\hline UP-525 & female & 13.8 & 4.7 & 39.3 & 84 & 1.2 & 11.6 & 99.7 \\
\hline UP-528 & female & 14.7 & 4.6 & 41.7 & 90 & 0.8 & 11.9 & 120.0 \\
\hline UP-1037 & female & 11.3 & 4.3 & 36.7 & 85 & 2.2 & 12.5 & 117.5 \\
\hline UP-1038 & female & 13.5 & 5.0 & 41.3 & 84 & 2.1 & 10.5 & 142.0 \\
\hline UH-7 & male & 14.4 & 5.5 & 42.5 & 78 & 2.6 & 12 & n.d. \\
\hline UH-15 & male & 12.2 & 4.6 & 36.1 & 78 & 2.3 & 12.5 & n.d. \\
\hline UH-36 & female & 12.6 & 4.8 & 36.9 & 77 & 2.3 & 11.1 & n.d. \\
\hline TRJ-21 & female & 13.9 & 5.3 & 43.1 & 80 & 1.9 & 4.5 & 115 \\
\hline TRJ-99 & female & 13.8 & 5.4 & 43.1 & 80 & 2.4 & 11.7 & 85.5 \\
\hline KJG-16 & female & 12.8 & 4.8 & 40.0 & 83 & 1.5 & 19.2 & 98.4 \\
\hline KJG-21 & male & 13.3 & 4.6 & 41.2 & 89 & 2.0 & 13.8 & 110 \\
\hline KJG-128 & male & 12.5 & 4.3 & 39.1 & 90 & 2.0 & 11.4 & 108.5 \\
\hline
\end{tabular}

Normal ranges are: $\mathrm{Hb}$ - male $13.0-16.0 \mathrm{~g} / \mathrm{dl}$, female $12.0-14.0 \mathrm{~g} / \mathrm{dl} ;$ red blood cell count - male $4.5-6.5 \times 10^{12} / \mu 1$, female $4.0-6.0 \times 10^{6} / \mu \mathrm{l}$; Hematocrit - male 40.0-48.0\%, female 37.0-43.0\%; MCV - 82-92fL; $\mathrm{HbA}_{2}:<3.5 \%$; Ferritin $<12 \mu \mathrm{g} / \mathrm{l}=$ iron deficiency. Bold values are outside the normal range

UP-029 and UP-030 are siblings; UP-1014 and UP-1015 are sister and father of UP-376, respectively; UP-516 to UP-519 are children of UP-512; UP-522 is a child of UP-515; UP-523 to UP-525 are siblings; UP-1037 and UP-1038 are children of UP-528

$\mathrm{HbO}$, hemoglobin $\mathrm{O}$; $\mathrm{MCV}$, mean cell volume; n.d., not determined

${ }^{a} \mathrm{HbA}_{2}$ was seen in the electrophoresis gels, but the Bio-Rad Model GS-700 Imaging Densitometer could not measure the very low levels

the levels in the Toraja population $(1.2 \%)$ or the small, isolated Kajang population $(1.7 \%)$. This observation is of interest in terms of the phylogenetic relationships among the four ethnic populations and their relation to the other populations of the archipelago.

The populations of South Sulawesi investigated in the present study include three of the major ethnic populations of the archipelago, after the Javanese and Sundanese of the island of Java (population 75 and 27 million, respectively) and the Malay of the east coast of Sumatra and the Malaysian peninsula (population size approx. 25 million), with the population for the Bugis, Makassar, and Toraja being 3.5, 1.6, and 0.5 million, respectively (Grimes 1999). Together with the Mandar (population 136,000) and the minor Kajang population $(45,000)$, they inhabit neighboring regions in South Sulawesi (Fig. 1) but have distinct languages and cultural characteristics.

The finding of $\mathrm{HbO}$ in four populations of South Sulawesi but not in other populations of the archipelago suggests that the mutation occurred relatively recently, dur- ing the early settlement of the southern region of Sulawesi Island by proto-Austronesian-speaking ancestors, perhaps, according to archeological data, some 3000 years ago (Bellwood 1995). The fact that in 19 independent cases examined the causal mutation was found to be the same, i.e., a GAG to AAG substitution at codon 116 of the $\alpha_{1}$ globin gene (Glu116Lys), is consistent with this suggestion, and further suggests that the $\mathrm{HbO}$ mutation has occurred only once. While further study to identify the $\alpha$-globin gene haplotypes associated with the $\mathrm{HbO}$ mutation is required for a definitive proof of a single origin, the fact that the mutation could not be found outside South Sulawesi, either in Indonesia (this study) or in neighboring Southeast Asia (Huisman et al. 1996) strongly argues for the hypothesis.

Our recent phylogenetic analysis of 28 ethnic population of the Indonesian archipelago based on the sequence polymorphism of the hypervariable region 1 (HVR 1) of the control D-loop region of the mtDNA (P. Pramoonjago and S. Marzuki, unpublished observation) showed clustering of the Austronesian-language-speaking populations of the 
archipelago into three clades. The Bugis and the Makassar are closely related and belong to a phylogenetic cluster. The Toraja, on the other hand, belong to a separate cluster, together with the Palembang and Banjar populations of South Sumatra and South Kalimantan. The high frequency of $\mathrm{HbO}$ in the Toraja (1.2\%) relative to the Bugis and Makassar suggests that the origin of the mutation was in the Toraja population and that it spread to the Bugis and Makassar presumably through inter-population marriages, even though such marriages were rare in the past.

The finding of a high prevalence of $\mathrm{HbO}$ in the Kajang population is interesting but not easy to interpret. The population is a self-isolated religious community of only 45,000 living in a closed area of $129 \mathrm{~km}^{2}$. Linguistically, the population speaks the Konjo language, which is related to, although distinct from, the Makassar language. One interpretation of our result, therefore, is that the Kajang population was derived from the Toraja but adopted the Konjo language of the neighboring populations at some stage.

A phenotypically similar $\mathrm{HbO}$ has been reported in an Iranian family (Rahbar et al. 1975) and in an Italian (Marinucci et al. 1978) family. Although the exact mutation responsible for this $\mathrm{HbO}$ phenotype has not been defined, electrophoretic analysis of tryptic digests of the $\beta$-globin chain did indicate a mutation similar to that observed in the South Sulawesi populations, i.e., a glutamic acid to lysine substitution at amino acid residue 116. A possibility thus exists that the $\mathrm{HbO}$ mutation is actually of a Middle Eastern origin and that it was introduced to South Sulawesi by Persian traders, perhaps soon after A.D. 1000, during the early phase of the introduction of Islam to the archipelago. This possibility, however, is remote because while the Bugis and the Makassar who inhabit the coastal region were converted through interactions with traders (Pelras 1996), the Toraja population, in which the $\mathrm{HbO}$ frequency is significantly higher, lived in isolation until quite recently in mountainous inland of South Sulawesi; most of the Torajas remained animists until the end of the last century.

Our results are also of interest in terms of the phenotypic expression of the $\mathrm{HbO}$ mutation. The replacement of negatively charged glutamic acid by positively charged lysine at residue 116 is structurally significant and thus could potentially lead to a functional or assembly defect. The HbO level in all but two of our cases was in fact found to be significantly lower $(10.1 \%$ to $13.8 \%)$ than that expected from a stable $\alpha_{1}$-globin variant; stable $\alpha_{1}$-variants have been reported to be present in the range of $16.9 \%$ to $22.5 \%$ (Molchanova et al. 1994). The level of $\mathrm{HbO}$ has been determined previously in two studies only. In one study involving two families, it was reported to be in the range of $16.4 \%$ to 28.5\% (Marinucci et al. 1978). However, the level of $\mathrm{HbO}$ in this early study was not properly determined because of the inability to separate $\mathrm{HbO}_{\text {Ina }}$ from $\mathrm{HbA}_{2}$ by the electrophoretic procedure available. In the other study of a single case (Weatherall and Clegg 1981), the level (8.4\%) was closer to that found in the present study. In our study, the $\mathrm{HbO}$ level was measured accurately by two independent procedures; in both procedures (electrophoretic analysis on cellulose acetate and HPLC analysis in the Variant hemo- globin testing system), the $\mathrm{HbO}$ was well separated from $\mathrm{HbA}_{2}$.

In the present study, we showed that $\mathrm{HbO}$ is stable in vitro, consistent with the previous study of Molchanova et al. (1994). An $\alpha 1$-globin gene carrying a HbO mutation is transcribed normally, and its mRNA represents around $21 \%$ of the total $\mathrm{Hb}$ mRNA (Molchanova et al. 1994). Our hemoglobin analysis data, therefore, suggest that the $\mathrm{HbO}$ mutation is associated with instability of either the $\alpha^{\text {OIna }}$-globin chain or with less efficient assembly of the hemoglobin in vivo, which has been shown to be one of the consequences of the $\beta$-globin Glu26Lys amino acid changes associated with the HbE mutation (Huisman 1997). Indeed, in 8 out of 32 cases investigated in the present study, the $\mathrm{Hb}$ level was found to be either in the lower end of the normal range ( 2 cases) or slightly below ( 6 cases). This suggestion is supported by the extremely low level of $\mathrm{HbA}_{2}$ seen in most of our patients, and is consistent with the milder phenotype of homozygous $\beta$-thalassemia observed in one individual, who carried a heterozygote $\mathrm{HbO}$ mutation as well (Weatherall and Clegg 1981). We are continuing our search for individuals homozygous for $\mathrm{HbO}$ to study further the functional abnormalities associated with this mutation, and for individuals with $\mathrm{HbO} / \beta$-thalassemia to investigate whether $\mathrm{HbO}$ ameliorates the clinical expression of $\beta$ thalassemia mutations.

Acknowledgments We thank Professor A.S. Sofro for allowing us to examine the DNA samples collected as part of the molecular anthropological study at the University of Gadjah Mada Inter University Centre. This work was supported in part by the Risbin Iptekdok grant No. 015/SPK/DOK/1996 from the National Research Council to DD. The Eijkman Institute is supported by grants from P.T. Krakatau Steel and P.T. Inti through the Agency for Strategic Industries (Indonesia).

\section{References}

Baglioni C, Lehmann H (1962) Chemical heterogeneity of hemoglobin O. Nature 196:229-232

Bellwood P (1995) Austronesian prehistory in Southeast Asia: homeland, expansion and transformation. In: Bellwood P, Fox JJ, Tryon D (eds) The Austronesian: historical and comparative perspectives. The Australian National University, Canberra, pp 96-111

Brozovic M, Henthorn J (1995) Investigation of abnormal hemoglobins and thalassemia. In: Dacie JV, Lewis SM (eds) Practical hematology, 8th edn. Churchill Livingstone, Edinburgh, p 249

Carrell RW, Kay R (1972) A simple method for the detection of unstable haemoglobins. Br J Hematol 23:615

Grimes BF (1999) Ethnologue, $13^{\text {th }}$ edn. SIL International Dallas, Texas

Huisman THJ (1997) HbE and $\alpha$-thalassemia: variability in the assembly of $\beta^{\mathrm{E}}$-chain containing tetramers. Hemoglobin 21:227-236

Huisman THJ, Carver MFH, Efremov GD (1996) A syllabus of human hemoglobin variants. The Sickle Cell Anemia Foundation, Augusta, GA, USA

Ko TM, Hwa HL, Liu CW, Li SF, Chu JY, Cheung YP (1999) Prevalence study and molecular characterization of alpha-thalassemia in Filipinos. Ann Hematol 78:355-357

Lie-Injo LE (1957) A new hemoglobin in the Buginese? Lancet 2:1338

Lie-Injo LE, Sadono (1958) Haemoglobin O (Buginese X) in Sulawesi. Br Med J 1:461-1462

Marinucci M, Mavilio F, Tentori L, Alberti R (1978) Hb O Indonesia $\left(\alpha_{2} 116(\mathrm{GH} 4)\right.$ Glu $\rightarrow$ Lys $\left.\beta_{2}\right)$ in association with $\beta$-thalassemia. Hemoglobin 2:59-63 
Molchanova TP (1993) A new screening test for unstable hemoglobins using n-butanol and red blood cells. Hemoglobin 17:251-255

Molchanova TP, Pobedimskaya DD, Huisman THJ (1994) The differences in quantities of $\alpha 2$ - and $\alpha 1$-globin gene variants in heterozygotes. Br J Hematol 88:300-306

Pelras C (1996) The Bugis. Blackwell, Oxford

Rahbar S, Nowzary G, Poosti M (1975) A double heterozygous hemoglobin. Hemoglobin $\mathrm{O}_{\text {Indonesia }}$ and hemoglobin $\mathrm{D}_{\text {Punjab }}$ in an individual. Am J Clin Pathol 64:416-420
Setianingsih I, Williamson R, Marzuki S, Harahap A, Tamam M, Forrest S (1998). Molecular basis of $\beta$-thalassemia in Indonesia: application to prenatal diagnosis. Molecular Diagnosis 3:11-20

Sofro AS (1995) Molecular pathology of $\beta$-thalassemia in Indonesia. Southeast Asian J Trop Med Pub Health 26:5-8

Weatherall DJ, Clegg JB (1981) The thalassemia syndromes. Blackwell, Oxford 